\title{
RARE SPECIES OF SHIELD-HEAD VIPERS IN THE CAUCASUS
}

\author{
Boris S. Tuniyev \\ Sochi National Park, Russia \\ e-mail:btuniyev@mail.ru
}

Received: 03.10.2016

\begin{abstract}
An overview is presented on shield-head vipers of the genus Pelias distributed in the post-Soviet countries of the Caucasian Ecoregion. The assessment presents the current conservation status and recommendations to vipers' territorial protection.
\end{abstract}

Key words: Caucasian Ecoregion, shield-head vipers, current status, protection.

\section{Introduction}

The Caucasian Ecoregion (the territory southward from the Kuma-Manych depression to northeastern Turkey and northwestern Iran) is the centre of taxonomic diversity of shield-head vipers within the genus Pelias Merrem, 1820, of which 13-18 species are found here. Without exception, all species have a status of the different categories of rareness, they are included on the IUCN Red list, or in the current and upcoming publication of National and Regional Red Data Books. Besides the shieldhead vipers the Caucasian Ecoregion inhabit three representatives of mountain vipers of the genus Montivipera Nilson, Tuniyev, Andren, Orlov, Joger \& Herrman, 1999 (M. raddei (Boettger, 1890), M. wagneri (Nilson \& Andren, 1984) and M. albicornuta (Nilson \& Andren, 1985)), one representative of the genus Vipera Laurenti, 1768 (V. transcaucasiana (Boulenger, 1913)), one representative of the giant vipers genus Macrovipera Reus, $1927-M$. lebetina obtusa (Dwigubsky, 1832) and one species of the genus Gloydius Hoge \& Romano-Hoge, 1981 (G. halys caucasicus (Nikolsky, 1916).

In this report, an overview is presented on shield-head vipers of the genus Pelias distributed in the post-Soviet countries of the Caucasian Ecoregion. The assessment presents the current conservation status and recommendations to vipers' territorial protection.

\section{Material and Methods}

We started the study of Caucasian viperidae snakes in 1979. Material was collected during numerous expeditions, semi-stationary and stationary works throughout the Caucasian Isthmus within the borders of the Russian Federation, Transcaucasian countries (Armenia, Georgia, Azerbaijan, Abkhazia and South Ossetia), as well as in north-eastern Turkey (Tuniyev B.S., 1990a, 1996, 2002, 2008a,b; Tuniyev B.S. \& Tuniyev S.B., 2006a,b; Tuniyev B.S. et al., 2009, 2014). On the routes we made geobotanical and phy- to-landscape descriptions (Tunieyv B.S. et al., 2009; Tuniyev S.B. et al., 2012, 2014). The stationary works (mostly on the territory of the Caucasian State Nature Biosphere reserve and Sochi National Park) conducted a study of the microclimatic features of vipers' habitats including temperature and humidity modes of air and the upper soil horizon. The results were compared with thermobiological characteristics of the animals (Tuniyev B.S. \& Unanian, 1986; Tuniyev B.S. \& Volčik, 1995). In a number of cases difficult to determine the taxonomic affiliation, in addition to the classical methods of animal morphology and statistics, biochemistry and molecular-genetic analysis methods have been applied (Nilson et al., 1994, 1995, 1999; Zinenko et al., 2011, 2015). The status of a species population, globally as well as on regional level assessed, is based on the IUCN Red List Categories and Criteria: version 3.1 and the Guidelines for Application of IUCN Red List Criteria at Regional Levels (Tuniyev B.S., 2007; Tuniyev B.S. \& Tuniyev S.B., 2007a, 2009, 2013a,b,c,d; Ananjeva et al., 2009).

\section{Results}

Shield-head vipers of the Caucasus within Russia and the Transcaucasian countries are represented by nine species. The following is an overview of these nine representatives of the genus Pelias and their current conservation status on the Caucasian Isthmus.

Darevsky's viper - Pelias darevskii (Vedmederja, Orlov \& Tuniyev, 1986) (Fig. 1). From the moment of the description of Darevsky's viper this species was considered as a local endemic of northwestern Armenia, although already a description possibility of its finding was assumed in the contiguous districts of Georgia (Orlov \& Tuniyev B.S., 1986). The new finds of the species in Armenia (Agasian \& Agasian, 2008) were located in the direct neighbourhood $(12 \mathrm{~km})$ of the type locality and actually did not extend the known distributional area of the species. In July 2014 the species was found 
by us in Ninotsminda, Akhalkalaki, Aspidindza, Akhaltsihe districts of Somkheto-Javakheti Region of Georgia at Javakheti Highland (Mt. Madatapa) and Erusheti Mountains (Mt. Gumbati, Mt. Airilanbashi) (Tuniyev S.B. et al., 2014). The established guidance on finding the Darevsky's viper in Turkey (Geniez \& Teynie, 2005; Avc1 et al., 2010; Tuniyev B.S. et al., 2009; Göçmen et al., 2014) at a considerable distance from the known sites were of great interest. Our research in Turkey showed that the vicinity of Posof inhabits another species - Pelias olguni (Tuniyev S.B. et al., 2012), the taxonomic status of other finds is in preparation.

The density of the populations of the species in Armenia is extremely low, as is the number of vipers in the identified locality in Georgia. The main threats are the killing of animals, overgrazing, trapping for the illegal zoo trade. So, the expansion of Darevsky's viper's distribution range cannot substantially be influenced by its conservation status. The Darevsky's viper still remains a narrowly distributed and sporadically spread species, not forming high-dense populations. The category rarities on the global population are estimated as CR B2ab (ii, iii). The species is listed on the IUCN Red list and in the Red Data Book of Armenia (2010).

Pelias darevskii is effectively protected exclusively in Arpilich National Park (Armenia). It is necessary to create a Protected Area on the Jahavakheti Highland and Erusheti Mountains in Georgia, as well as to work on the optimisation of borders for a plot of Mt. Madatapa in Georgia which borders with the Arpilich National Park, so that biotopes of Darevsky's viper can be included into this new Protected Area.

Dinnik's viper - Pelias dinniki (Nikolsky, 1913) (Fig. 2). It is endemic to the Highlands of the Great Caucasus, sporadically distributed within the Russian Federation, republics of Abkhazia, Georgia and South Ossetia (Tuniyev B.S. et al., 2009). In the Russian Federation, it is known from the republics of Adygea, Karachay-Cherkessia, Chechnya and Dagestan (Tuniyev B.S. \& Tuniyev S.B., 2009). During the last decade the understanding of the range of the species has significantly expanded. We have found isolated populations on Mt. Zhitnaya of Lagonaksky Ridge, Adygea (north-western limit), the tops of Hakudzh, Lysaya of Chernomorsky Chain, Krasnodarsky Krai (western limit) (Tuniyev B.S. \& Tuniyev S.B., 2007a, 2013a); in the vicinity of pass Genukh and the upper basin of the river Dzhurmut, Dagestan (eastern limit). In addition, new localities have been discovered on Aibga Ridge (Krasnodarsky Krai), Kutakheku Ridge (Abkhazia), the upper basin of the river Bolshaya Liakhvi (South Ossetia), and in other locations. There are not yet reliable data on the species' presence in the republics of North Ossetia-Alania, Kabardino-Balkaria and Ingushetia, but finding of the species is quite possible there.

The density of the vipers' populations varies in the various parts of the range, except in the territory of the Caucasian reserve, where there is a decrease in the number of specimens. In the most favourable habitats there can be found up to 30 animals per 1 hectare. In Chechnya and Dagestan the species is extremely rare, sporadically distributed on most mesophylls parts of the subalpine belt.

The main threats for the western populations are the recreational development, construction of ski facilities on the territory of Sochi National Park, the planned mastering of the Caucasian reserve, development of Resorts in the North Caucasus on existing protected territories; for the eastern populations overgrazing and absence of high rank protected areas (reserves and national parks) are the main threats. The category rarities on the global population is estimated as VU B1ab (iii,v), in a forthcoming new edition of the Red Data Book of the Russian Federation the category VU C1+2a.

Dinnik's viper is listed on the IUCN Red list, in the Red Data Book of the Russian Federation (2001), Krasnodarsky Krai (2007), the republics of Adygea (2012), Karachay-Cherkessia (2013), Chechnya (2007), Dages$\tan (2009)$ and in the first planned edition of the Red Data Book of the Republic of South Ossetia.

The species is protected on the territory of the Caucasian and Teberdinsky reserves, a part of the population is protected on the territory of Sochi and Ritza relic national parks. To save the polymorphic populations of the species, it is necessary to abandon ambitious plans for transformation of natural landscapes in the Highlands of the Sochi National Park (Aibga Ridge) (Tuniyev B.S. \& Timukhin, 2015) and in the Caucasian Reserve (basins of the upper flowing of the river Mzymta and Malaya Laba); also it is necessary to create a new federal Protected Area in the Itum-Kalinskaya depression of the river ChantyArgun (on base of the former Soviet Sanctuary) in Chechnya and cluster plots of the Dagestan Reserve on the river Tokhor and slopes of Mt. Guton and the neighborhood of the Genukh mountain pass.

Erevan mountain-steppe viper - Pelias eriwanensis (Reuss, 1933) (Fig. 3). This endemic relict species has a disjunctive distribution on the southern slopes of the Lesser Caucasus and the Armenian Highland. The species range includes Armenia, Azerbaijan, Turkey and Northwestern Iran (Rajabizadeh et al., 2011). Recently, the species has been found on the shores of Lake Kartsakhi in South Georgia (Tuniyev S.B. et al., 2014) and on Bargushat Ridge in Armenia. 


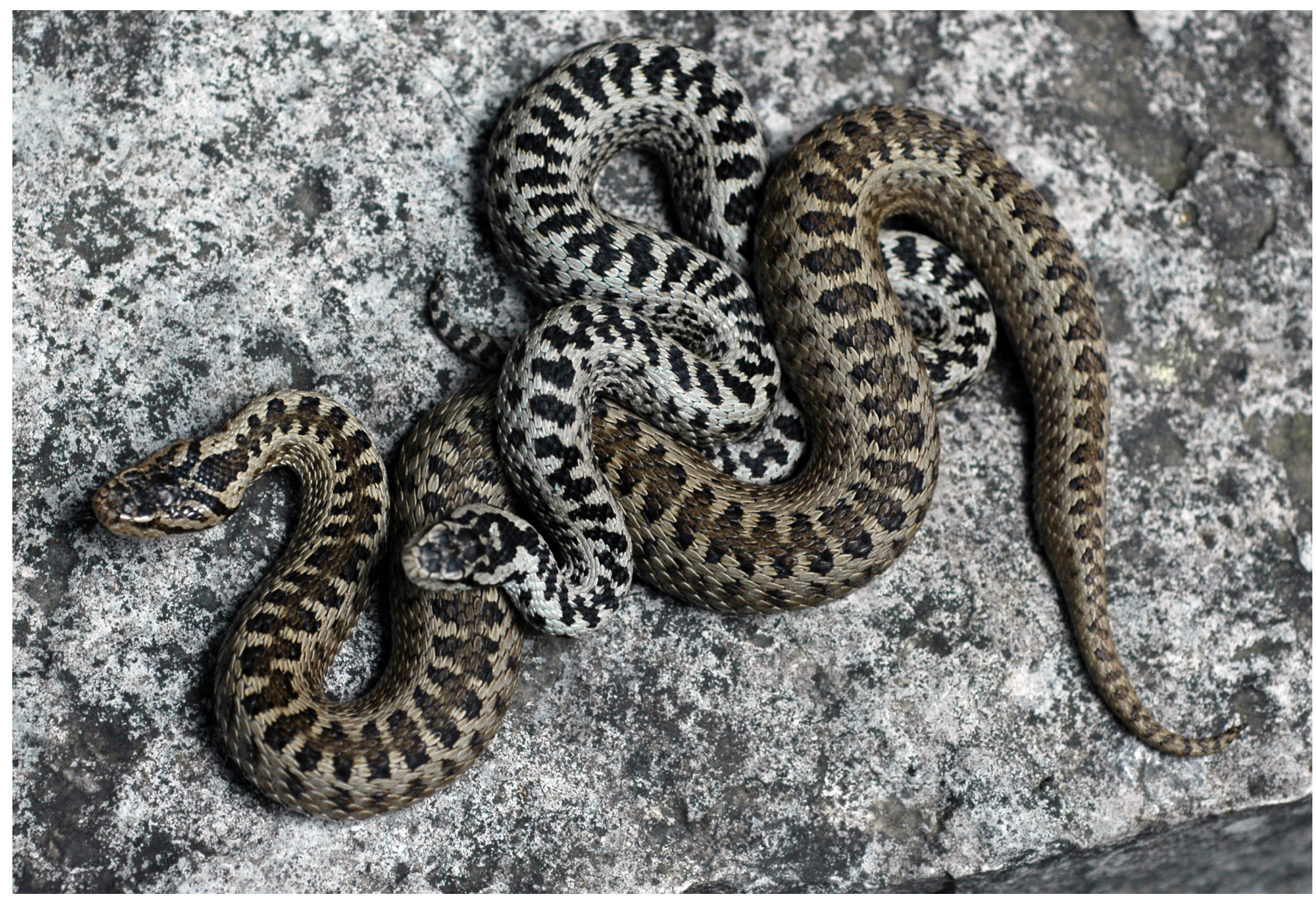

Fig. 1. Pelias darevskii (Vedmederja, Orlov \& Tuniyev, 1986): upper - male, below - female, South Georgia, Mt. Gumbati.

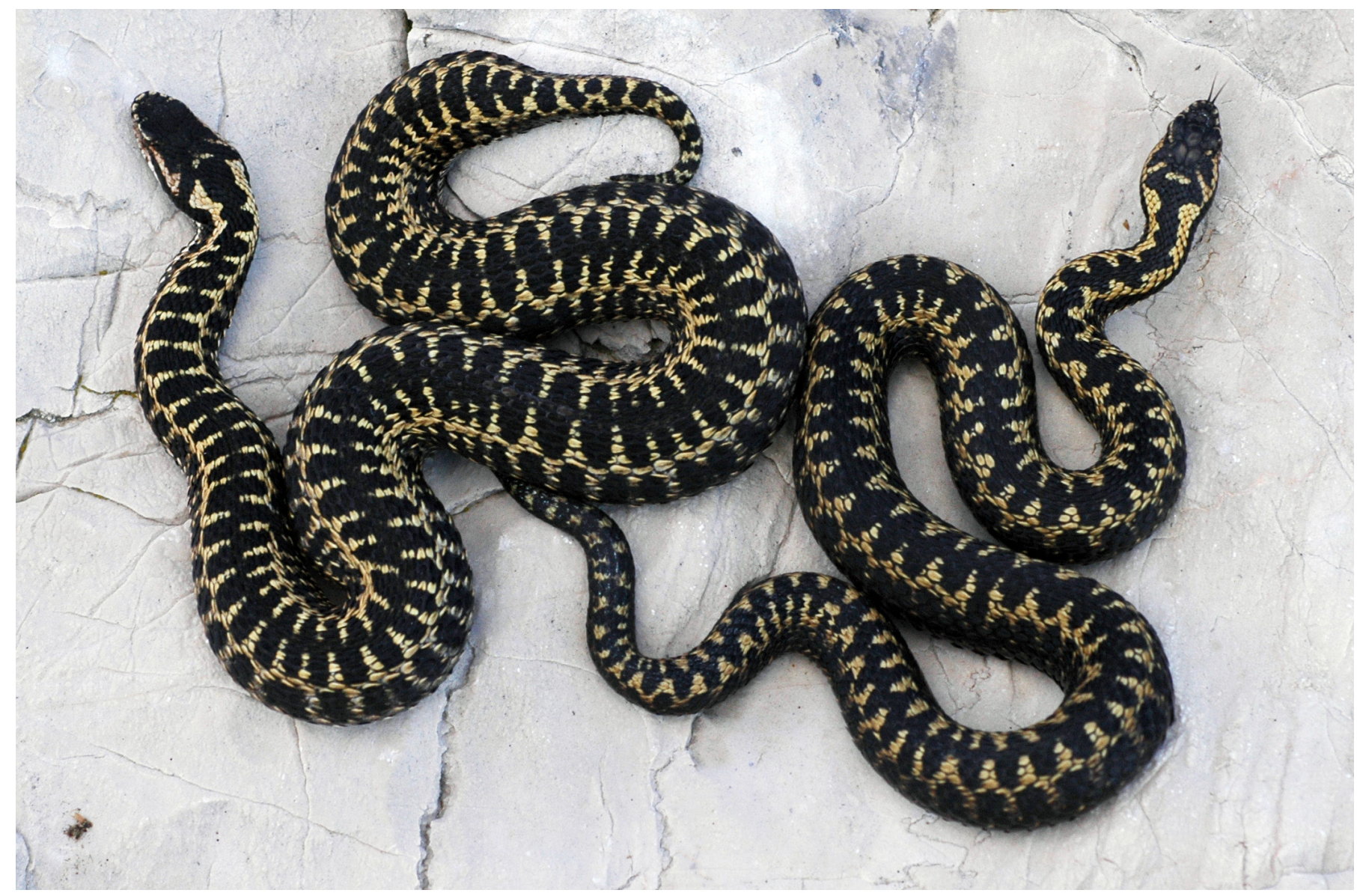

Fig. 2. Pelias dinniki (Nikolsky, 1913): female (left), male (right), Abkhazia, ridge Kamenny Klad. 


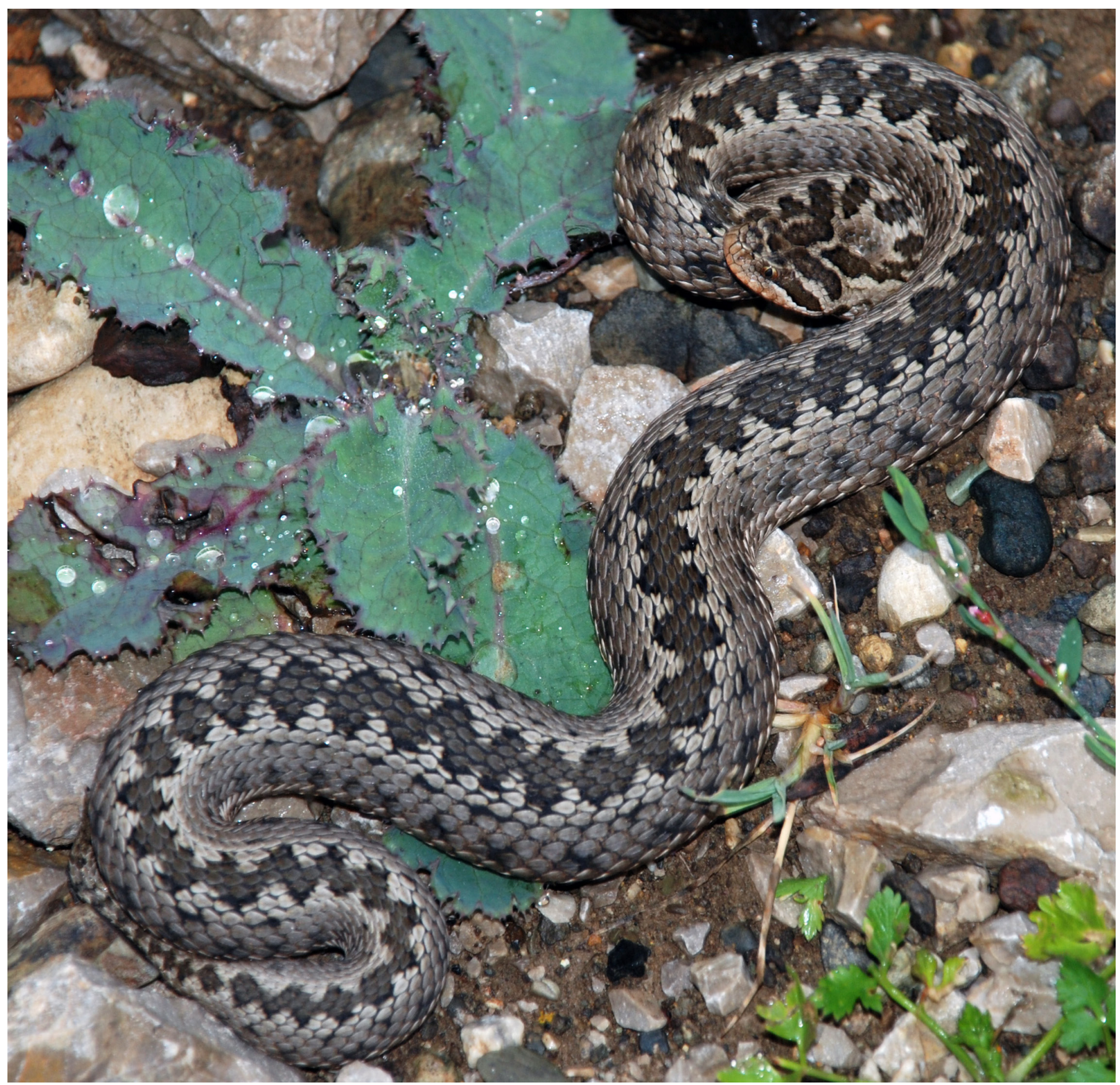

Fig. 3. Pelias eriwanensis (Reuss, 1933), female. Turkey, Mt. Kysyrdag.

Isolated populations inhabit rocky mountain steppe, meadow-steppe, juniper bushes on the slopes of dormant volcanoes and arid ridges (Urc, Karabakh, etc.), rarely rise down along the canyons of the rivers to the middle-mountain belts, where the steppe outliers in the canyons (Kasakh River, Armenia). Nowhere the species forms a high density, often we met single animals, rarely up to 5 specimens at $1 \mathrm{~km}$ of the route.

The main threats are the killing of animals and destruction of their habitats, overgrazing both in the Transcaucasian Republics and in Turkey. The category rarities on the global population is estimated as VU Blab(iii,v). The species is listed in the Red Data Book of Armenia (2010). It is necessary to list the species in the Red Data Books of Azerbaijan and Georgia.

The Erevan mountain-steppe viper is currently protected in Armenia in the Khosrov reserve territory, formally defined in Sevan National Park and Zangezur Sanctuary. The species habitats on Urc (former Sarajbulag) Ridge has dropped out from under protection in connection with the deletion of this site from the Khosrov Reserve. To save the species requires the creation of a transboundary protected area around Kartsakhi Lake in South Georgia and Turkey, and creating local reserves on the coast of Childyr Lake in Turkey.

Caucasian (Kaznakov's) viper - Pelias kaznakovi (Nikolsky, 1909) (Fig. 4). This is an oppressed relict endemic of Colchis having slight irradiations. It is sporadically distributed in foothill areas of Krasnodarsky Krai, republics of Abkhazia, Adygea, Western Georgia and Adzharia within the former Soviet Union and on the Lazistan coast of Turkey (Orlov \& Tuniyev B.S., 1986), as well as it is known disconnectedly in Eastern Georgia - in Borzhomi Gorge (Bakradze, 
1969). In the Russian Federation, the area covers the foothill areas along the Black Sea coast from the vicinity of the town Tuapse to the border with Abkhazia, on the northern slope of the Western Caucasus from the town Goryachy Kluch to the foothills of Apsheronsky District of Krasnodarsky Krai and Tulsky district of the Republic of Adygea (Tuniyev B.S. \& Tuniyev S.B., 2007b, 2013b). In recent years, the species has been found on some new localities in Turkey (Afsar \& Afsar, 2009) and it has been noted for the first time on the territory of South Ossetia (Tuniyev B.S. et al., 2016).

Pelias kaznakovi has never been numerous and now progressively disappears throughout the area. In many places where it was observed in the twentieth century, now either disappeared or preserved unsustainable dwindling micropopulations. So, at the end of the last century in the vicinity of the town Tuapse there were counted up to 3 specimens on 100 $\mathrm{m}^{2}$ (Ostrovskikh, 1991), currently the Caucasian viper is on the verge of extinction in this locality. The largest population remained in the Sochi National Park, where you could meet on a day trip up to 10 specimens (Tuniyev B.S. \& Tuniyev S.B., 2007b).
Currently, most biotypes are destroyed or heavily transformed in connection with the construction of Olympic venues and involving them in the infrastructure of the Mzymta - Psou rivers area. Apparently, the total number of specimens of this species in the Russian Federation is not more than 2000.

The main threats are the killing of animals and destruction of their habitats, intensive trapping for the illegal zoo trade, recreational mastering the Black Sea coast of the Caucasus, to change the zoning of the Sochi National Park, with the transfer of plots of vipers and the protected habitat of protected zones in the lower category of zoning. The category rarities on the global population is estimated as EN B2ab(ii,iii,v), in a forthcoming new edition of the Red Data Book of the Russian Federation in category EN A4abcd; B2ab(i,ii,iii,iv,v). Pelias kaznakovi is listed on the IUCN Red list, in the Red Data Book of the former USSR (1984), Red Data Book of the former Georgian Soviet Socialist Republic (1982), Red Data Books of Russian Federation (2001), Krasnodarsky Krai (2007), Republic of Adygea (2012), as well as in the Red Data Book of the Republic of South Ossetia (first edition is being prepared at the moment).

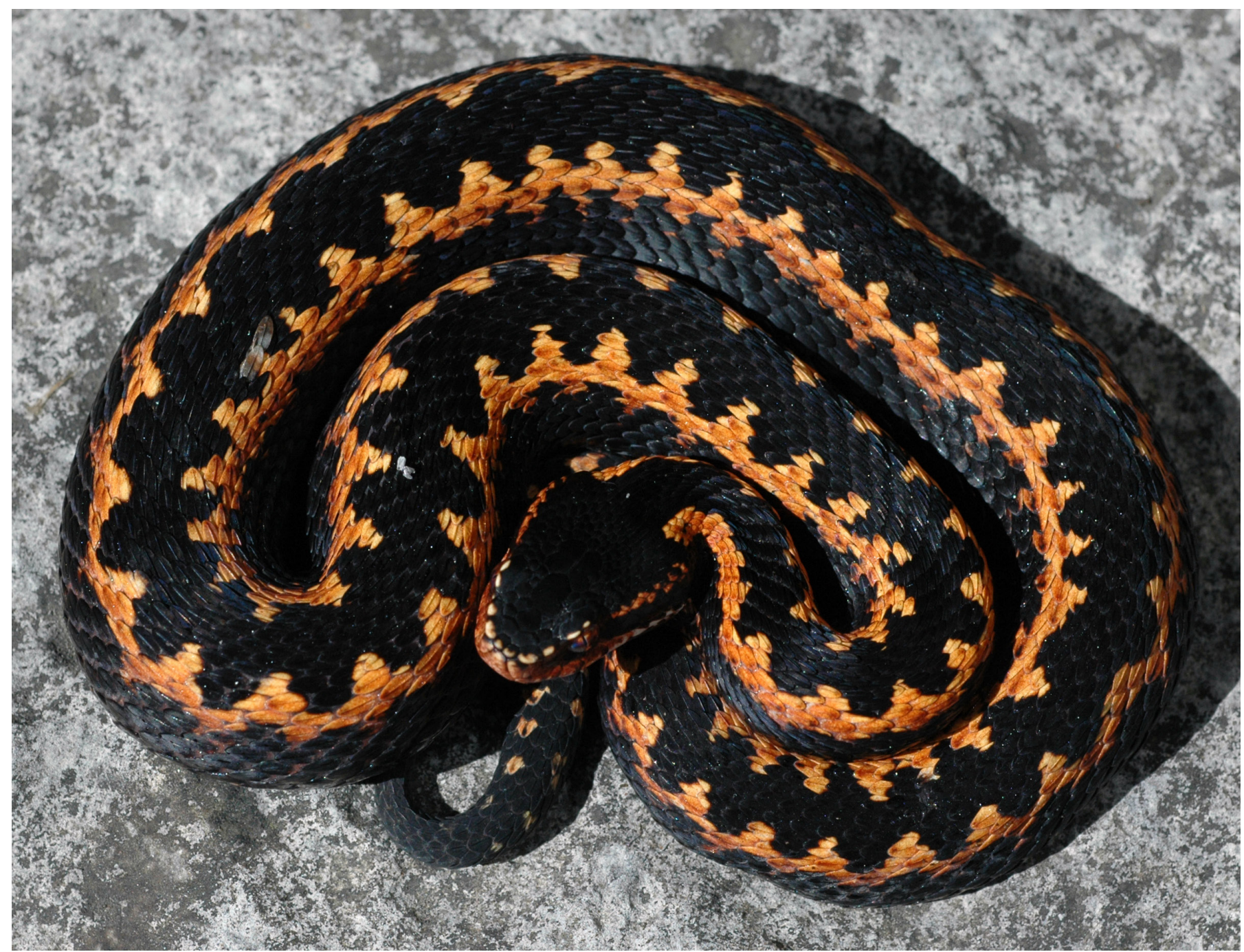

Fig. 4. Pelias kaznakovi (Nikolsky, 1909), female. Russian Federation, Mt. Mosya. 
The bulk of the range in Russia remains on the territory of Sochi National Park, small populations are found in the Caucasian reserve. Formally, the species is protected in Ritza relict National Park, Pskhu-Gumista reserve (Abkhazia), in the Kintrish reserve and Mtirala National Park (Georgia), the South-Ossetia reserve (South Ossetia).

To save this species all places with a dense habitation of Pelias kaznakovi in Sochi National Park should be included in the functional zoning in an especially protected or reserved zone. Important is the breeding of the species in captivity with subsequent reintroduction.

Lotiev's viper - Pelias lotievi (Nilson, Tuniyev, Hoggren, Orlov \& Andren, 1995) (Fig. 5). The declining in the number of this rare endemic species probably represents a complex of cryptic forms. The total area covers mainly the middle mountain area of the Great Caucasus within Russia, with little penetration into Georgia and Azerbaijan. In the Russian Federation the distribution range is found in semi-arid depressions in the Eastern and Central Caucasus, where it inhabits shibliaks ${ }^{1}$, frigana, mountain-steppe areas from 1200 up to $1800 \mathrm{~m}$ above sea level. In the Krasnodarsky Krai it is found in the midlands band at an altitude of 1500-1700 m above sea level, where Pelias lotievi inhabits xerophylous subalpine meadows, scrubs and rocky associations and talus slopes. When described only eight localities of the species were known (Nilson et al., 1995; Nilson \& Andren, 2001), due to our numerous expeditions, covering the whole of the Northern Caucasus (Tuniyev S.B. et al., 2011) nowadays a detailed distribution of the species is known with about 70 localities. In the East the range of Pelias lotievi reaches coastal Dagestan in the vicinity of the settlement Izerbash (Kolichi River), covering almost the entire foothill and mountainous Dagestan, except in the highland sections of the Main Ridge. To the West, Pelias lotievi inhabits semi-arid depressions of Chechnya, Ingushetia, North Ossetia-Alania, xerophylous slopes of Mt. Elbrus and Skalisty (Rocky) Ridge in Kabardino-Balkaria, and further westward is a chain of isolate sites in hemixerophylous landscapes of Bokovoy (Forward) and Skalisty (Rocky) ridges in the Karachay-Cherkessia Republic up to the extreme western finds at the watershed of Bolshaya Laba and Malaya Laba Rivers in the Krasnodarsky Krai (Tuniyev B.S. \& Tuniyev S.B., 2007c).

The species is locally able to form plots of high density: up to 40 specimens per 1 ha. Usually no more than 3 animals per $1 \mathrm{~km}$ route in mountainsteppe are found; it is rare in the subalpine belt.

1 Shibliak - thickets of deciduous shrubs in Mediterranean regions
The rarity of this species in the Krasnodarsky Krai is associated with natural reasons of mismatching of modern climatic and environmental conditions to ecological requirements of this mountain-steppe species. For the same reasons, Pelias lotievi is rare in Georgia (known only from the northern slope of the Main Ridge). The main threats are overgrazing, reducing the protective properties of biotopes, direct destruction of man, and weak coverage of the habitats of the species by the existing network of high rank protected areas, e.g. reserves and national parks. The category rarities on the global population is estimated as NT, in relation to the total area of the species, not exceeding $20,000 \mathrm{~km}^{2}$. Pelias lotievi is listed in the Red Data Books of Krasnodarsky Krai (2007), Chechnya (2007) and Karachay-Cherkessia (2013).

An isolated population is protected in the territory of the Caucasian reserve, part of the range is included in Teberdinsky (Karachay-Cherkessia) and Erzi (Ingushetia) Reserves. It is formally preserved on the territory of Charodinsky Sanctuary in Dagestan. It is necessary to create new protected areas in Sadono-Unal'skaya depression of North-OssetiaAlania, Itum-Kalinskaya depression of Chechnya, and in several places of inner-mountain Dagestan.

Relic viper - Pelias magnifica (Tuniyev \& Ostrovskikh, 2001) (Fig. 6). This oppressed endemic relict species has a limited number of habitats, conservation depends even on short anthropogenic influences. The entire area is located in the Russian Federation and covers Skalysty (Rocky) Ridge within Krasnodarsky Krai, Republic of Adygea; possibly it occurs in the Karachay-Cherkessia Republic (Tuniyev B.S. \& Ostrovskikh, 2001). The species range covers the so-called Belo-Labinsky Refugia of Colchis biota (Tuniyev B.S., 1990) and it is a complex version of derivates of the Colchic vegetation enriched with elements of Mediterranean and even of steppe vegetation. Habitats are represented by light oak groves, dry stretches of grassy meadows and shrubs on rocky limestone cornices of arrays in the range of heights from 700 up to 1000 $\mathrm{m}$ above sea level.

The population density is extremely low: on a day excursion no more than three specimens were seen (Tuniyev B.S. \& Tuniyev S.B., 2007d, 2013c). In 2014, during the countings, on a day trip no more than four specimens were observed; the average was one specimen per day excursion. Sometimes all day we were not able to meet any viper (Tuniyev S.B. et al., 2016). The main threats are the naturally archaic area, which constantly highlights the grassroots fires, increasing recreational press, trapping animals for illegal zoo trade. 


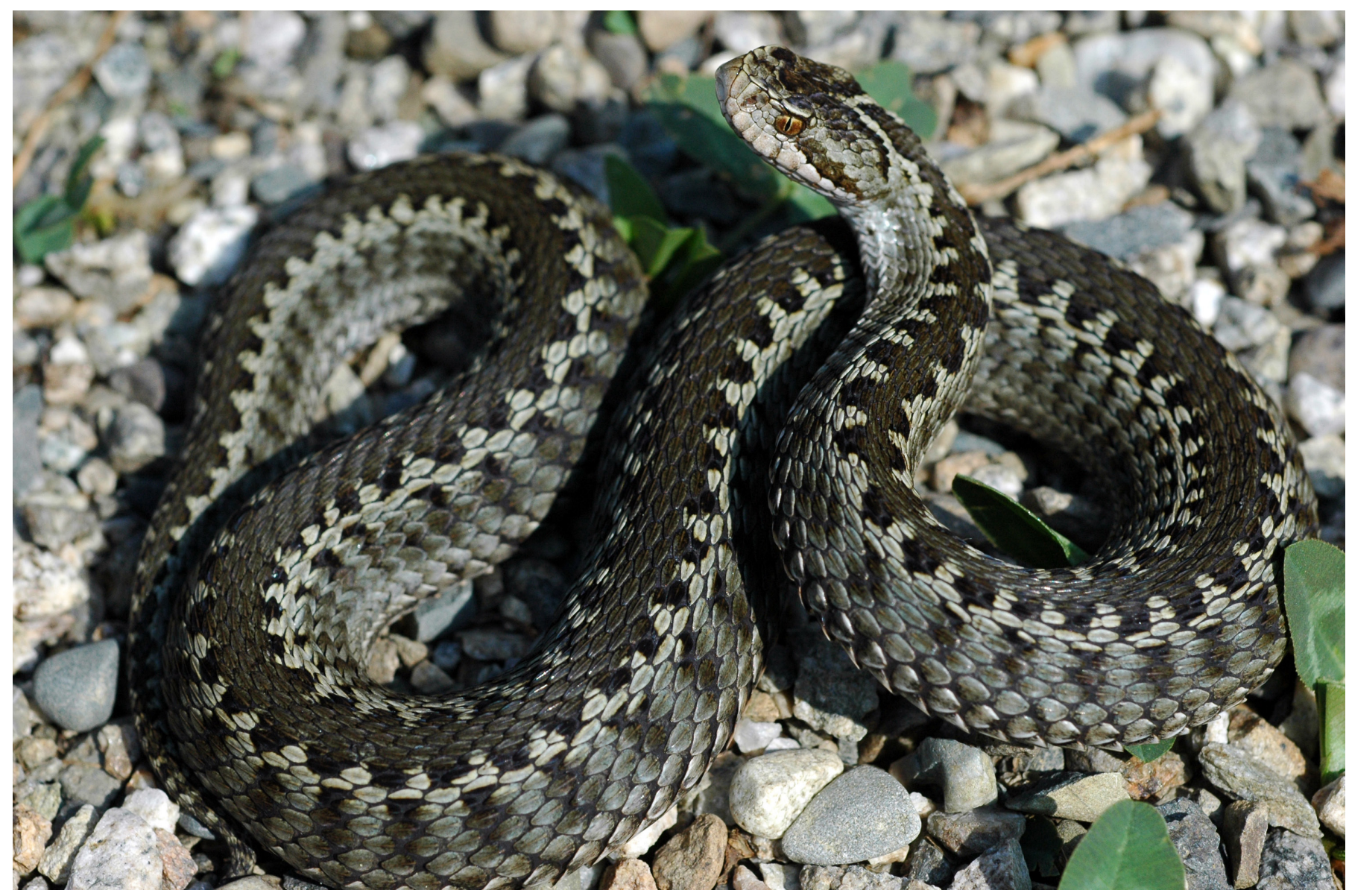

Fig. 5. Pelias lotievi (Nilson, Tuniyev, Hoggren, Orlov \& Andren, 1995), female. Russian Federation, Karachay-Cherkessia Republic, Ridge Abishir-Akhuba.

Pelias magnifica is included on the IUCN Red List, category EN A1cd $+2 \mathrm{CD}$, in the Red Data Book of Krasnodarsky Krai (2007) with category NT and the Red Data Book of the Republic of Adygea (2012) with category CR A4abc;B2ab(i,ii,iii,v)(c)(iv). Thus, a rapid assessment of the year 2014 allowed stating the existence of a small stable, exposed to anthropogenic limiting factors, population of the Relic Viper on the type locality and we agree to the terms on the IUCN Red List category of threats for the existence of the species within Krasnodarsky Krai - EN $\mathrm{A} 1 \mathrm{~cd}+2 \mathrm{~cd}$. An insignificant part of the population is protected in the Caucasian reserve, to which it is necessary to include the Maly Bambak Ridge.

Orlov's viper - Pelias orlovi (Tuniyev \& Ostrovskikh, 2001) (Fig. 7). This is an endangered endemic relict species declining progressively. The entire area is located in the Krasnodarsky Krai of the Russian Federation and covers both slopes of the lowest Northwestern part of the Greater Caucasus from Mt. Papay in the west to peak Bolshoy Pseushkho in the east (Tuniyev B.S. \& Ostrovskikh, 2001). The distribution area lies entirely within the area of influence of the Mediterranean climate and development of xeromesophyt habitats. The species occurs in different versions of submediterranean landscapes: from intrazonal riparian glades to steppe-meadows and ecotones of juniper forests. The high-altitude distribution ranges from 450 up to $950 \mathrm{~m}$ above sea level.

The number of specimens is very low. At the end of the last century no more than three specimens were seen on a day excursion (Tuniyev B.S. \& Tuniyev S.B., 2007e). Rapid assessment in 2014-2016 indicates the disappearance of this species on some locations (northern foot of Palay Mt., neighbourhood of Gelendzhik, etc.) and a catastrophic decrease of the population density in the surviving habitats. The main threat is illegal trapping of animals for zoo trade. The category rarities on the global population is estimated as $\mathrm{CR}$ $\mathrm{B} 1 \mathrm{ab}(\mathrm{i}, \mathrm{v}) ; \mathrm{C} 2 \mathrm{~A}(\mathrm{i})$, in a forthcoming new edition of the Red Data Book of the Russian Federation as category EN A2abcd. It is listed on the IUCN Red List and in the Red Data Book of Krasnodarsky Krai (2007).

For saving Pelias orlovi it is necessary to organise a cluster plot of the Utrish Reserve at Mt. Papay, or to create a full-fledged Novorossiysk Reserve, in accordance with the earlier recommendations (Tuniyev B.S. \& Nilson, 1995), as well as implementing the decision of UNEP within the framework of the compensatory actions Sochi-2014 Winter Olympics to include in the area of the Sochi National Park Mt. Bolshoy Pseushkho (Tuniyev B.S. \& Timukhin, 2013). 


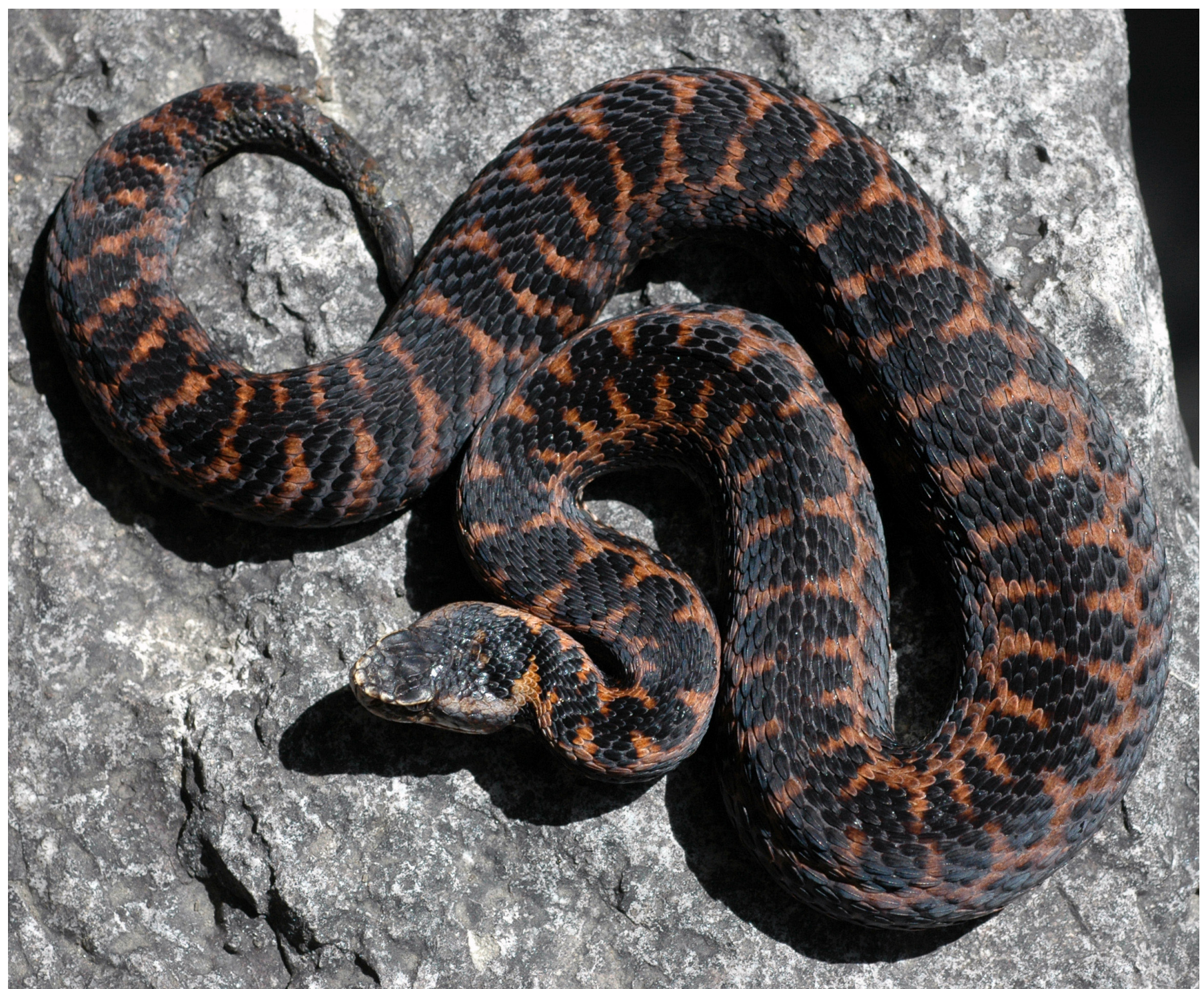

Fig. 6. Pelias magnifica (Tuniyev \& Ostrovskikh, 2001), female. Russian Federation, ridge Maly Bambak.

East steppe (Renard's) viper - Pelias renardi (Christoph, 1861) (Fig. 8). The range of this species has decreased previously and it continues to decrease currently under the influence of human activities. The total area covers the steppe and semi-desert area of the South-Eastern European countries, Kazakhstan and Central Asia. In the Russian Federation, it is found from the Volga-Kama region north to the Precaucasia region south and Central Altai Mountains in the east (Ananjeva, et al., 2004). In the Caucasian Ecoregion area it covers the lowland and the foothills of the Northern Caucasus. According to our observations, Pelias renardi maximally penetrates into mountainous country in the area of the Central Caucasus.

This species is found on the plains of various types (loess, alluvial-loess, terraced), on hills, in lower-mountain belts. It inhabits forest edge, shrub associations, shibliaks, steppe slopes (Ostrovskikh, 2003; Ostrovskikh \& Plotnikov, 2003a). In the southeast of the range in Krasnodarsky Krai it occurs at altitudes up to $1000 \mathrm{~m}$ a.s.l., and it is able to live on the sandy sea spits (Tuniyev B.S. \& Tuniyev S.B., 2007f). In conditions of anthropogenic landscape it forms narrow, stripe-like settlements in badlands and bargain sites, tree planting, etc. (Ostrovskikh \& Plotnikov, 2003b). In the Central Caucasus, in the area of the Mt. Elbrus gap forest vegetation, Pelias renardi, together with other steppe species of plants and animals, penetrates mountains up to $1500 \mathrm{~m}$ a.s.1.

At the end of the last century in habitats in the Caucasus we saw up to 30 animals per one hectare (Ostrovskikh, 2003). Currently the number of habitats and the number of snakes has declined sharply. Major threats remain steppe and forest-steppe landscape transformation and the direct killing by man. The category rarities on the global population is estimated as VU A1c+2c, in a forthcoming new edition of the Red Data Book of the Russian Federation as category VU A4cd;B1ab(i,ii,iii,iv). Pelias renar$d i$ is listed on the IUCN Red List, in the Caucasus Ecoregion - in the Red Data Books of Stavropolsky Krai (2013), Krasnodarsky Krai (2007), republics of Dagestan (2009), Chechnya (2007), KarachayCherkessia, 2013), Adygea (2012). 


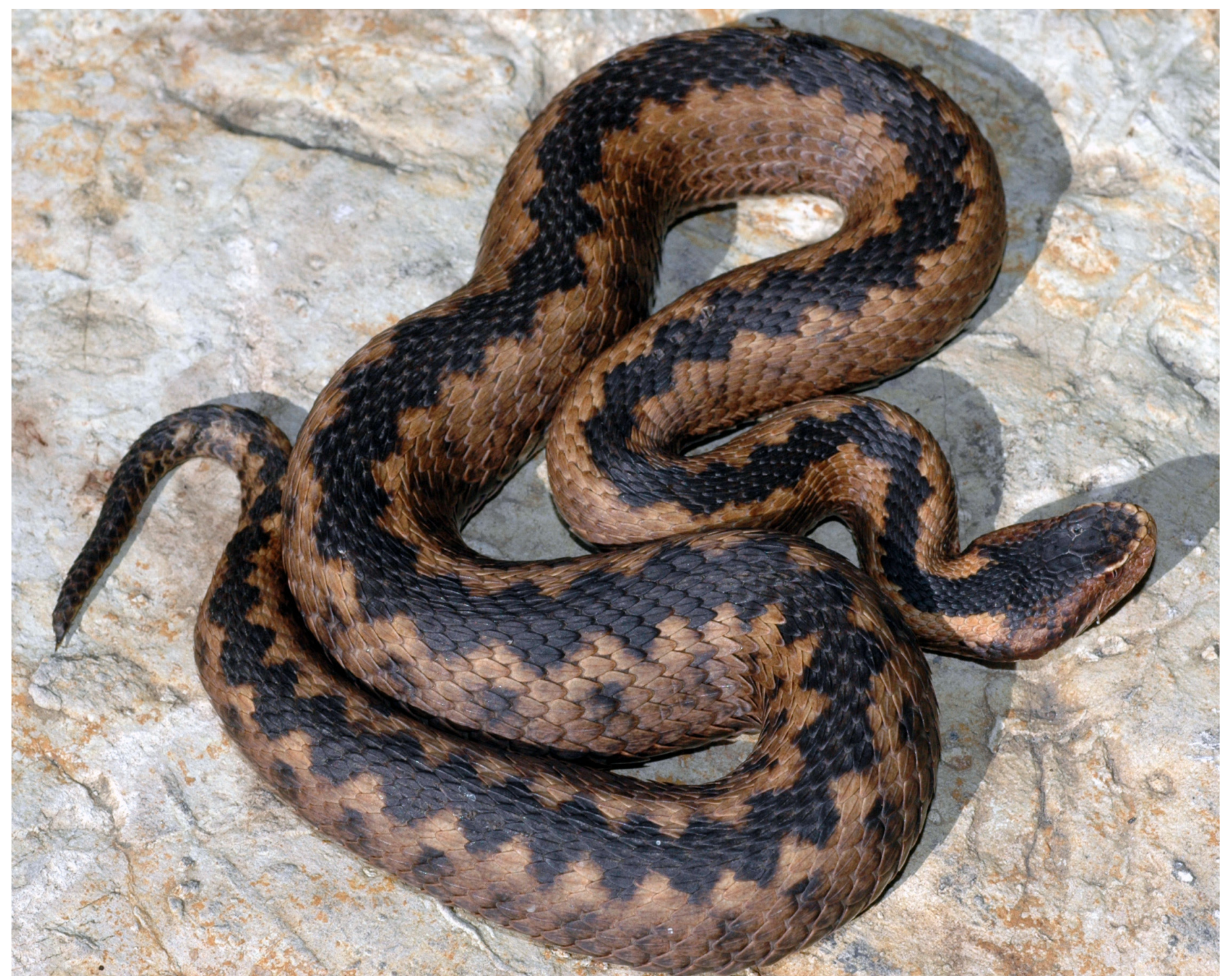

Fig. 7. Pelias orlovi (Tuniyev \& Ostrovskikh, 2001), female. Russian Federation, Mt. Soberbash.

The species is unprotected almost everywhere in the Caucasian part of the range. A tiny population is located near the northern border of the Utrish Reserve. The organisation of cluster areas in existing nature reserves in locations of dense occurrence of vipers is necessary. It is necessary to extend the recently established Kislovodsk National Park, with inclusion of Pelias renardi's biotopes located in the Region of Caucasian Mineral Waters.

Schemakha viper-Pelias schemakhensis Tuniyev, Orlov, Tuniyev \& Kidov, 2013 (Fig. 9). This is a narrow-endemic, oppressed relict species, whose area covers the Schamakhi District of Azerbaijan. Until recently, the species was considered missing in the northeastern steppe regions of Eastern Georgia. However, in 2016, it was re-found here (Tuniyev B.S. \& Iremashvili, 2017). Alekperov (1978) specified that in the vicinity of Schemakha a viper occurs at an altitude of $700 \mathrm{~m}$ a.s.l. in the stony area of mountains, covered by xerophylous grasses and shrub vegetation, also in the small agricultural sowing, in the heaps of stone on the plough-lands and along the roads. According to our observations, the biotopes of the species (both in Azerbaijan and in Georgia) are presented by shibliaks of Paliurus spina-christi Mill. and ecotones of dry Andropogon steppes and derivates of the broad-leaved forests on the stony slopes of foothills. In other words, vipers were ousted from steppes habitats into biotopes unusual for them: these have been recently the broad-leaved forests with an extreme variant of degradation - Paliurus' shibliak (Tuniyev S.B. et al., 2014).

Presumably this viper used to be locally numerous. Dzhanashvili (1951) noted that in 1944 thirteen specimens were killed in Shirak Steppe within 15 $\mathrm{km}$. Alekperov (1978) recorded numerous specimens originated from Schemakha: only for feeding study 22 specimens were dissected. At present, the species has become very rare in Northeast Azerbaijan, and in Northeast Georgia it is on the verge of extinction. Pelias schemakhensis (under the name Pelias renardi) was included in the Red Data Book of Azerbaijan (2013) as a rare taxon limited in range and abundance. Pelias schemakhensis should be included on the IUCN Red List and in the Red Data Book of Georgia with the status CR B1ab(i,ii,iii,iv,v). 


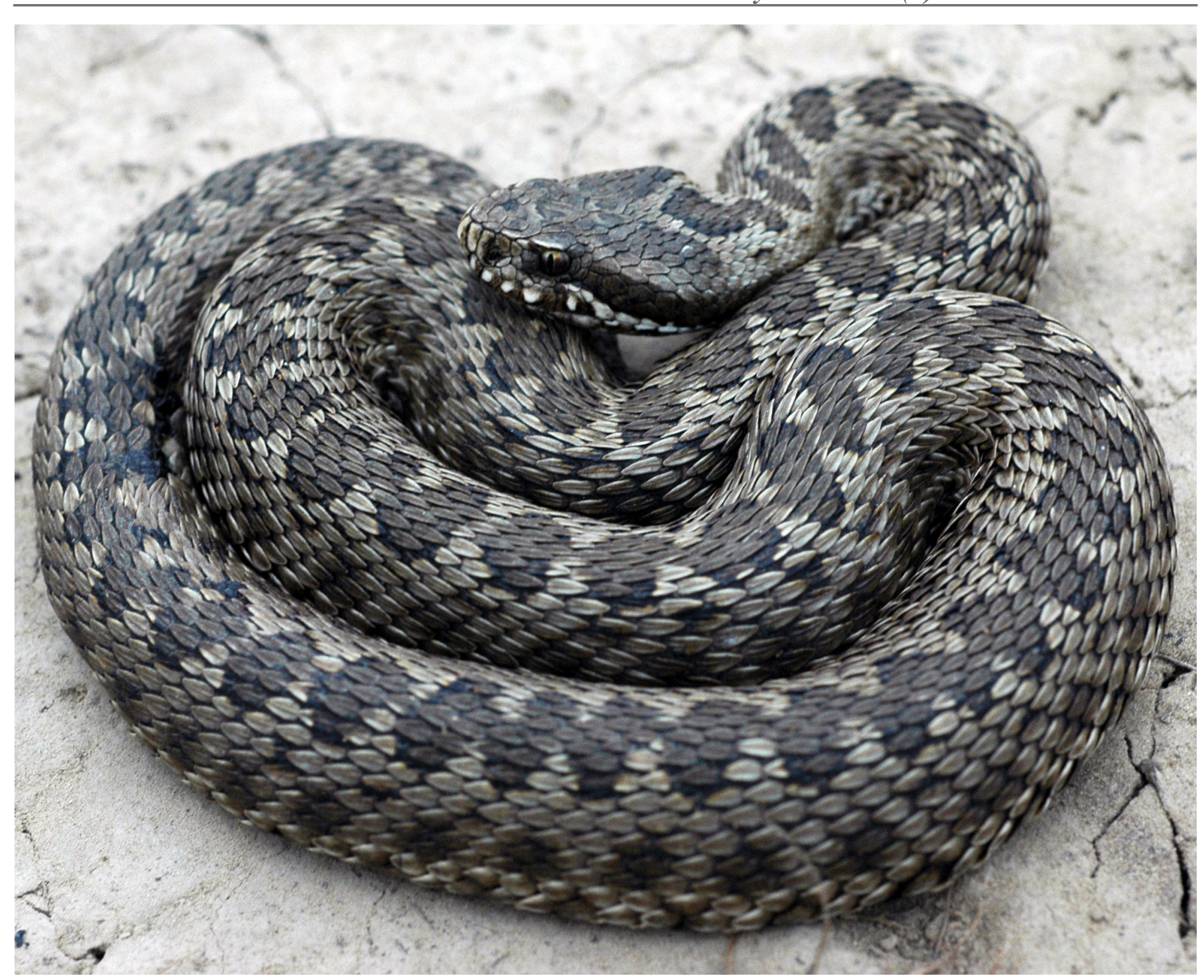

Fig. 8. Pelias renardi (Christoph, 1861), female. Russian Federation, Kalmyk, Lake Manych.

To save the species, preferably as soon as possible protected areas in the vicinity of Schemakha in Azerbaijan have to be established and cluster plots of the Vashlovani Reserve on the Shirak plateau in Georgia.

\section{Discussion}

Snakes are one of the most sensitive components of natural ecosystems; negatively reacting to natural changes, in connection with the problem of their protection is particularly relevant. A few species are capable of sinanthropisation. Moreover, given the fear of man before snakes and their direct killing, there are no chances of these animals protect themselves against humans. It remains to say that prolonged retention of viable populations of snakes may occur primarily within protected areas (Tuniyev B.S. et al., 2011).

Over the past 100 year of investigation of viperidae snakes in the Caucasus, the number of genera of these reptiles has increased very significantly here: from 2 (Vipera, Agkistrodon) up to 5 (Vipera, Pelias, Montivipera, Macrovipera, Gloydius), while the species number increased from 7 up to 19 (among them 13 species of shield-head vipers of the genus Pelias). This indicates a very high species diversity of the genus Vipera sensu lato in the Caucasus.

In the formation of viperidae snakes should be recognised the significant role of cryptic speciation. If we trace the history of the study of Caucasian vipers of the genus Pelias for 100 years, the tendency of the selection of the cryptic species is obvious from the value of the Caucasian Viper (P. kaznakovi). Originally, the species was divided into three taxa: Vipera kaznakovi Nikolsky, 1909 s.str. (= Pelias kaznakovi), Vipera dinniki (Nikolsky, 1913) (= Pelias dinniki) and Vipera darevskii Vedmederja, Orlov \& Tuniyev, 1986 (= Pelias darevskii) (Vedmederja et al., 1986; Orlov, Tuniyev B.S., 1986; Orlov, Tuniyev B.S., 1990). The later described cryptic species Vipera magnifica Tuniyev \& Ostrovskikh, 2001 (= Pelias magnifica) and Vipera orlovi Tuniyev \& Ostrovskikh, 2001 (= Pelias orlovi), and noted from north-eastern Turkey Pelias darevskii (Avc1 et al., 2010) was described as a cryptic species - Pelias olguni (Tuniyev S.B. et al., 2012). 


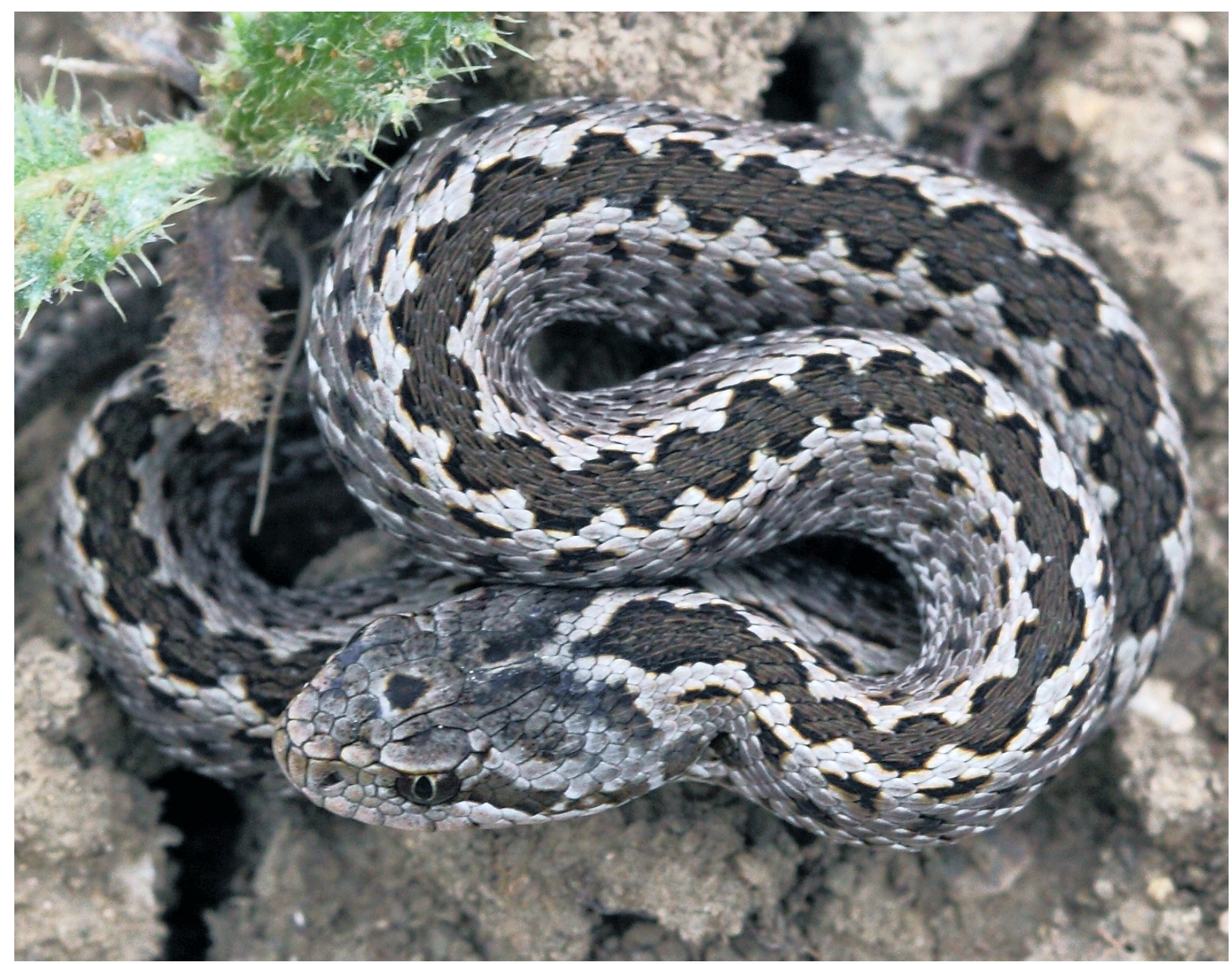

Fig. 9. Pelias schemakhensis Tuniyev, Orlov, Tuniyev \& Kidov, 2013. Azerbaijan, vicinity of Maraza.

A similar picture of cryptic speciation is noted in the Eastern steppe Viper (Pelias renardi), for a long time considered as a subspecies of the European steppe Viper - Vipera ursinii renardi (Christoph, 1861). Vipera lotievi (Nilson, Tuniyev, Hoggren, Orlov \& Andren, 1995) (= Pelias lotievi) was described from the middle-mountains of Northern Caucasus; Pelias schemakhensis was recognised at foothills of the south slope of the East Caucasus. At the species rank were raised Pelias eriwanensis and Pelias ebneri. All of these forms were previously considered in the scope of Pelias renardi.

Noted (Tuniyev S.B. et al., 2011) morphological deviations from the original descriptions of Pelias lotievi in several populations in belly colour, in the parietal spot, zigzag bends and loreal shield separating the nasal from the upper preocular shield can be indication of hybrid origin with multiple hybridisation.

In other words, hybrids could emerge several times and at various points both from the current pair of high-mountain species (P. lotievi, P. dinniki), and with the participation of extinct taxa. The role of forming natural hybridisation in the Caucasus, lead- ing to active speciation, shown by Darevsky (1967), became clear by the classical research Rock Lizards of the genus Darevskia Arribas, 1999. For two key groups (Rock lizards and Shield-head vipers) in the Caucasian Ecoregion are especially characteristic the high taxonomic diversity and active speciation in connection with the process named "habitats insularisation" in mountain regions (Brown, Lamolino, 1998), where a powerful drainage system, heterogeneity of climate and vegetation create a great diversity of biotopes and contribute to island effect of speciation. Based on the nature of disjunctive distribution of many species, likely to be the relict-insular nature of their spread in the Caucasian Ecoregion (Tuniyev B.S. et al., 2011).

Discovering of the high level of diversity of shield-head vipers in the Caucasian Ecoregion is essential to establish the conservation status of rare and narrow-distributed species, the vast majority of whom are included on the IUCN Red list. Despite the importance of preserving the biodiversity of all the snakes in the Caucasian Ecoregion, the main task and responsibility on a global scale is to pre- 
serve endemic taxa of the Caucasus, which, with the exception of Pelias renardi, include all other shieldhead vipers of the Caucasus. In other words, this area plays a key role in the conservation of the vast number of species of shield-head vipers.

As can be seen above, protection of endemics as Pelias darevskii, $P$. dinniki, $P$. lotievi is relatively successful because significant parts of habitats of these vipers are located within nature reserves and national parks. At the same time not covered by protected areas are species like Pelias orlovi, $P$. schemakhensis; poorly represented within Protected Areas are Pelias kaznakovi, P. magnifica, P. ebneri and P. eriwanensis. Moreover, Pelias orlovi and $P$. magnifica habitats were not even included in the priority regions of the CEPF.

\section{Conclusion}

Above were given recommendations on the organisation of new, or the expansion of existing, protected areas of Caucasian Isthmus. Analysis of biological diversity and spatio-high-rise properties of specially protected natural territories and objects in the Caucasus showed that they failed to secure its objectives for the protection and rational use of natural resources full, including long-term guaranteed preservation of shield-head vipers. In some cases, international co-operation is needed to create such protected areas as East-Caucasian Transboundary Territory, uniting Mt. Guton, Tlyaratinsky Sanctuary, vicinity of Genukh pass, Lagodekhi and Zakataly State Reserves, Shakhdag National Park (Russia, Azerbaijan, Georgia); North Colchis Transboundary Territory, uniting Caucasian, Pskhu-Gumista, Pitsunda-Myussera Reserves, Sochi and Ritza National Parks (Abkhazia, Russia); Ashotsk-Javakheti Transboundary Territory, uniting the Arpilich National Park, Javakheti Highland and Erusheti Mountains (Armenia, Georgia, Turkey).

Protected Areas listed in our work do not exhaust the list of possible transboundary cooperation between Georgia and Turkey, between Armenia, Iran and Azerbaijan, which is the subject of a separate discussion. The implementation of this programme for the development of econet in the Region, along with suggested above other protected areas for the conservation of endemic and endangered species, will come as close to a sustainable long-term reliable completeness of viperidae snakes biodiversity conservation in the Caucasian Ecoregion.

\section{Acknowledgements}

Over the last 15 years, data on viper snakes have been collected, comprehended and processed by Sako Tuniyev (my son who perished tragically) using modern statistical techniques and molecular-genetic techniques; this material would never have seen the light without him, and I began writing this review in memory of him.

At different times in collecting material and joint expeditions invaluable assistance has been provided by I. Timukhin, K. Lotiev, A. Kidov, A. Avc1, V. Minasian, H. Aliyev, G. Iremashvili, B. de las Heras, A. Malkhasyan and others, to whom I express my sincere thanks.

Separate gratitude I want to express to N.B. Ananjeva for her continuous support to our research and friendship.

\section{References}

Alekperov A.M. 1978. Amphibians and reptiles of Azerbaijan. Baku: Elm. 262 p. [In Russian]

Afsar M, Afsar B. 2009. A new locality for Vipera (Pelias) kaznakovi Nikolsky, 1909 (Reptilia, Viperidae) in the North-Eastern Anatolia. Russian Journal of Herpetology 16 (2): 155-158.

Agasian L.A., Agasian A.L. 2008. New information about distribution and conservation of Darevsky's viper (Vipera darevskii Vedmederya, Orlov \& Tuniyev, 1986). Problems of Herpetology. Materials of the Third International conference of Herpetological Society named after A.M. Nikolsky. St.-Petersburg. P. 7-10. [In Russian]

Ananjeva N.B., Orlov N.L., Khalikov R.G, Darevsky I.S., Ryabov S.A., Barabanov A.V. 2006. The Reptiles of Northern Eurasia. Sofia; Moscow: Pensoft. 232 p. [In Russian]

Ananjeva N.B., Tuniyev B.S., Orlov N.L. 2009. Reassessment of the IUCN Red List for Amphibians and Reptiles of the Caucasus. In: Status and protection of Globally threatened species in the Caucasus. Tbilisi. P. 131-136.

Avcı A., Ilgaz Ç., Başkaya Ş., Baran I., Kumlutaş Y. 2010. Contribution to the distribution and morphology of Pelias darevskii (Vedmederja, Orlov \& Tuniyev, 1986) (Reptilia: Squamata: Viperidae) in Northeastern Anatolia. Russian Journal of Herpetology 17 (1): 1-7.

Bakradze M.A. 1969. New information on distribution of the Caucasian viper (Vipera kaznakowi Nikolsky) in Georgia. Reports AN Gruz. SSR 57 (2): 467-468. [In Russian]

Brown J.H., Lamolino M.V. 1998. Biogeography. Sinauer Associates. Sunderland, Massachusetts: Sinauer Associates, Inc. Publishers. 692 p.

Geniez F., Teynié A. 2005. Discovery of a population of the critically endangerous Vipera darevskii Vedmederja, Orlov \& Tuniyev, 1986 in Turkey, with new elements of its identification (Reptilia, Squamata, Viperidae). Herpetozoa 18 (3/4): 1-9.

Göçmen B., Mebert K., İğci N., Akman B., Yıldız Z., Oğuz M.A. and Çağatay A. 2014. New locality records for four rare species of vipers (Reptilia: Viperidae) in Turkey. Zoology in the Middle East 60 (4): 306-313. doi: 10.1080/09397140.2014.966518

Darevsky I. S. 1967. Rock Lizards of the Caucasus. Leningrad: Nauka. 214 p. [In Russian]

Dzhanashvivli A.G. 1951. Materials to investigation of reptiles distribution in Georgia. In: Proceedings of Tbilisi University 44: 3-19. [In Russian]

Nilson G., Andren C. 2001. The meadow and steppe vipers of Europe and Asia - the Vipera (Acridophaga) ursinii comlex. Acta Zoologica 47 (2-3): 87-267. 
Nilson G., Hoggren M., Tuniyev B., Orlov N., Andren C. 1994. Phylogeny of the vipers of the Caucasus (Reptilia, Viperidae). Zoologica Scripta 23 (4): 353-360.

Nilson G., Tuniyev B., Andren C., Orlov N. 1999. Vipers of Caucasus: Taxonomic Consideration. Kaupia, Darmstadter Beitrage zur Naturgeschichte 8: 103-106.

Nilson G., Tuniyev B., Andren C., Orlov N., Joger U., Herrmann H.-W. 1999. Taxonomic Position of the Vipera xanthina Complex. Kaupia. Darmstadter Beitrage zur Naturgeschichte 8: 99-102.

Nilson G., Tuniyev B., Orlov N., Andren C. 1995. The ShieldHeaded Vipers of the Caucasian Isthmus and Armenian Highland. In: Abstracts II Asian Herpetological Meeting. Ashgabat. P. 42.

Nilson G., Tuniyev B.S., Orlov N.L., Hoggren M., Andren C. 1995. Systematics of the Vipers of the Caucasus: Polymorphism or Sibling Species? // Asiatic Herpetological Research. Vol. 6. P. 1 - 26.

Orlov N.L., Tuniyev B.S. 1986. Modern areas, possible ways of their forming and phylogeny of three species of vipers of Euro-Siberian group of complex Vipera kaznakowi on Caucasus. Proceedings of Zoological Institute of AN SSSR 157: 107-135. [In Russian]

Orlov N.L., Tuniyev B.S. 1990. Three Species in the Vipera kaznakovi Complex (Eurosiberian Group) in the Caucasus: There Present Distribution, Possible Genesis, and Phylogeny. Asiatic Herpetological Research 3: 1-36.

Ostrovskikh S.V. 1991. On biology of Caucasian viper. In: Actual problems of ecology and Nature conservation of Black Sea coast. Part 1. Krasnodar. P. 159160. [In Russian]

Ostrovskikh S.V. 2003. Biology of steppe viper (Vipera renardi Christoph, 1861) on North-Western Caucasus. Abstract of doctoral thesis. Stavropol. 19 p. [In Russian]

Ostrovskikh S.V., Plotnikov G.K. 2003a. To spread the steppe Viper (Vipera renardi Christ., 1861) in the Krasnodar Territory and the Republic of Adygea. In: Actual problems of ecology and Nature conservation of south regions of Russia and adjusted territory. Krasnodar. P. 89-91. [In Russian]

Ostrovskikh S.V., Plotnikov G.K. 2003b. Tape settlements steppe Viper (Vipera renardi Christ.) in the anthropogenic landscape. In: Animals in anthropogenic landscape. Astrakhan. P. 48-50. [In Russian]

Rajabizadeh M., Nilson G., Kami H.G., Naderi A.R. 2011. Distribution of the subgenus Acridophaga Reuss, 1927 (Serpentes: Viperidae) in Iran. Iranian Journal of Animal Biosystematics 7 (1): 83-87.

Red Data Book of Georgian SSR. Rare and endangered species of animals and plants, Some Nature Monuments. Tbilisi, 1982. 225 p. [In Georgian]

Red Data Book of Karachay-Cherkessia Republic. Cherkessk: Natrizdat, 2013. 360 p. [In Russian]

Red Data Book of Krasnodarsky Krai (Animals). Vol. 1. Krasnodar, 2007. 504 p. [In Russian]

Red Data Book of Russian Federation (Animals). Moscow: Astrel, 2001. 860 p. [In Russian]

Red Data Book of the Republic of Adygea. Part 2. Animals. Majkop: Kachestvo, 2012. 376 p. [In Russian]

Red Data Book of the Republic of Azerbaijan. Rare and endangered animal species. Baku, 2013. 517 p. [In Russian]

Red Data Book of Dagestan. Plants and animals. Makhachkala: Dagestan publ., 2009. 552 p. [In Russian]

Red Data Book of the Republic of Ingushetia. Plants and animals. Magas: Serdalo, 2007. 368 p. [In Russian]
Red Data Book of the Republic of North Ossetia - Alania. Rare and endangered species of plants and animals. Vladikavkaz: Project-Press, 1999. 248 p. [In Russian]

Red Data Book of USSR. Rare and endangered species of animals and plants. Vol. 1. Moscow: Lesnaya promyshlennost, 1984. 392 p. [In Russian]

Red Data Book of Stavropolsky Krai. Vol. 2. Animals. Stavropol: Asterix, 2013. P. 157. [In Russian]

Red Data Book of the Republic of Chechnya. Rare and endangered species of plants and animals. Grozny, 2007. 432 p. [In Russian]

Red Data Book of Animals of the Republic of Armenia. Invertebrates and Vertebrates. Erevan, 2010. 367 p. [In Russian]

Tuniyev B.S. 1989. Rare amphibians and reptiles of Caucasian biosphere reserve. In: Rare and need in protection animals. Materials for Red Data Book. Proc. Sc. Works CNIL Glavokhoty RSFSR. Moscow. P. 96-101. [In Russian]

Tuniyev B.S. 1990a. Phenetic polymorphism of Dinnik's viper in upper basin of Mzymta River. In: Phenetic of wild populations. Moscow. P. 281-282. [In Russian]

Tuniyev B.S. 1990b. On the Independence of the Colchis Center of Amphibian and Reptile Speciation. Asiatic Herpetological Research 3: 67-84.

Tuniyev B.S. 1996. Rare and endangered representatives of herpetofauna of Krasnodar Territory and Adygea Republic. In: Actual problems of ecology and nature conservation of south and central regions of Russia. Krasnodar. P. 140-141. [In Russian]

Tuniyev B.S. 2002. Shield-head vipers of the Caucasus. In: Biodiversity of Caucasus. Sukhum. P. 288-294. [In Russian]

Tuniyev B.S. 2007. Conservation status of "kaznakovi"complex vipers of Krasnodarsky Krai. In: Actual problems of ecology and Nature conservation of south regions of Russia and adjusted territory. Krasnodar. P. 65-67. [In Russian]

Tuniyev B.S. 2008a. Results of thirty-year investigations of herpetofauna in Caucasian reserve. In: Proceedings of Caucasian State Nature Biosphere Reserve. Vol. 18. Majkop. P. 99-115. [In Russian]

Tuniyev B.S. 2008b. Breeding strategy of snakes the Caucasus Highlands. In: Problems of herpetology: Materials of III Congress of Herpetological Soc. named after A.M. Nikolsky. Saint Petersburg. P. 401-407. [In Russian]

Tuniyev B.S., Lotiev K.Yu., Tuniyev S.B., Gabaev V.N., Kidov A.A. 2017. Amphibians and reptiles of South Ossetia: history of study, faunistic composition, horology, zoogeographical analysis. Nature Conservation Research (in press). [In Russian]

Tuniyev B.S., Nilson G. 1995. Modern situation and perspective of conservation of the herpetofauna in the Western Transcaucasia. Scientia Herpetologica. P. 357-360.

Tuniyev B.S., Orlov N.L., Ananjeva N.B., Agasian A.L. 2009. Snakes of Caucasus. Taxonomical Diversity, Distribution, Conservation. Moscow: KMK. 223 p. [In Russian]

Tuniyev B.S., Orlov N.L., Ananjeva N.B., Aghasian A.L. 2011. Taxonomic diversity of ophidiofauna and problems of preservation of snakes in the Caucasian Ecoregion. In: Biodiversity and the protection of the fauna of the Caucasus. Erevan. P. 296-299. [In Russian]

Tuniyev B.S. Ostrovskikh S.V. 2001. Two new species of vipers of «kaznakovi» complex (Ophidia, Viperinae) 
from the Caucasus. Russian Journal of Herpetology 8 (2): 117-126.

Tuniyev B.S., Timukhin I.N. 2013. Mountain Bolshoy Pseushkho - new unique plot of Sochi National Park. In: Proceedings of scientific papers. Sochi: RIO SNIC RAN. P. 175-180. [In Russian]

Tuniyev B.S., Timukhin I.N. 2015. An exceptional conservation value of Aibga Ridge for biodiversity conservation in the Russian Federation. In: Proceedings of scientific papers. Sochi: RIO SNIC RAN. P. 160-170. [In Russian]

Tuniyev B.S., Tuniyev S.B. 2006a. Herpetofauna of FishtOshten Mountain Massive and Lagonaki Highland of Caucasian State Nature biosphere reserve. In: Problems of sustainable development of the regions of recreation specialization. Sochi: Sochi scientific and research center of the Russian Academy of Sciences. P. 193-205. [In Russian]

Tuniyev B.S., Tuniyev S.B. 2006b. Herpetofauna of Sochi National Park. In: Inventory of major taxonomic groups and communities, sozological study of the Sochi National Park is the first outcome of Russia's first National Park. Moscow. P. 195-204. [In Russian]

Tuniyev B.S., Tuniyev S.B. 2006c. Rare species of amphibians and reptiles of the Sochi National Park. In: Inventory of major taxonomic groups and communities, sozological study of the Sochi National Park is the first outcome of Russia's first National Park. Moscow. P. 205-225. [In Russian]

Tuniyev B.S., Tuniyev S.B. 2007a. Dinnik's viper (Pelias dinniki (Nikolsky, 1913)). In: Red Data Book of the Krasnodarsky Krai. Vol. 1. Animals. Krasnodar. P. 351-352. [In Russian]

Tuniyev B.S., Tuniyev S.B. 2007b. Kaznakov's viper (Caucasian viper) (Pelias kaznakovi (Nikolsky, 1909)). In: Red Data Book of the Krasnodarsky Krai. Vol. 1. Animals. Krasnodar. P. 353-354. [In Russian]

Tuniyev B.S., Tuniyev S.B. 2007c. Lotiev's viper (Pelias lotievi Nilson, Tuniyev, Hoggren, Orlov et Andren, 1995)). In: Red Data Book of the Krasnodarsky Krai. Vol. 1. Animals. Krasnodar. P. 354. [In Russian]

Tuniyev B.S., Tuniyev S.B. 2007d. Relic viper (Pelias magnifica (Tuniyev et Ostrovskikh, 2001)). In: Red Data Book of the Krasnodarsky Krai. Vol. 1. Animals. Krasnodar. P. 354-355. [In Russian]

Tuniyev B.S., Tuniyev S.B. 2007e. Orlov's viper (Pelias orlovi (Tuniyev et Ostrovskikh, 2001)). In: Red Data Book of the Krasnodarsky Krai. Vol. 1. Animals. Krasnodar. P. 355-356. [In Russian]

Tuniyev B.S., Tuniyev S.B. 2007f. Steppe viper (Pelias renardi (Christoph, 1861)). In: Red Data Book of the Krasnodarsky Krai. Vol. 1. Animals. Krasnodar. P. 356-357. [In Russian]

Tuniyev B.S., Tuniyev S.B. 2009. Conservation Strategy for Endemic Species of Caucasian Vipers (Pelias kaznakovi, P. dinniki). In: Status and protection of Globally threatened species in the Caucasus. Tbilisi. P. 165-169.

Tuniyev B.S., Tuniyev S.B. 2013a. Dinnik's viper (Pelias dinniki (Nikolsky, 1913)). In: Red Data Book of the Republic of Adygea. Rare and endangered animals and plants. Vol. 2. Animals. Majkop. P. 247-248. [In Russian]

Tuniyev B.S., Tuniyev S.B. 2013b. Caucasian viper (Pelias kaznakovi (Nikolsky, 1909)). In: Red Data Book of the Republic of Adygea. Rare and endangered animals and plants. Vol. 2. Animals. Majkop. P. 249. [In Russian]
Tuniyev B.S., Tuniyev S.B. 2013c. Relic viper (Pelias magnifica (Tuniyev \& Ostrovskikh, 2001)). In: Red Data Book of the Republic of Adygea. Rare and endangered animals and plants. Vol. 2. Animals. Majkop. P. 250. [In Russian]

Tuniyev B.S., Tuniyev S.B., Avc1 A., Ilgaz Ç. 2014. Herpetological reseachs in eastern and north-eastern Turkey. Current Studies in Herpetology 14 (1/2): 44-53. [In Russian]

Tuniyev B.S., Unanian E.S. 1986. Species composition and daily activity of reptiles of Khosrov State Reserve. Biological Journal Armenia 39 (7): 572-576. [In Russian]

Tuniyev B.S., Volčik S. 1995. On placing and thermobiology of polymorphic population of Vipera dinniki (Nikolsky, 1913) (Serpentes, Viperidae) at uppermost Mzymta river valley. Scientia Herpetologica. P. 244-249.

Tuniyev S.B., Avc1 A., Tuniyev B.S., Agasian A.L., Agasian L.A. 2012. Description of a New Species of Shield-Head Vipers - Pelias olguni sp. nov. from Basin of Upper Flow of the Kura River in Turkey. Russian Journal of Herpetology 19 (4): 307-313.

Tuniyev B.S., Iremashvili G.N. 2017. Rediscovery of steppe viper in Georgia. Russian Journal of Herpetology (in press). [In Russian]

Tuniyev S.B., Iremashvili G.N., de las Heras B., Tuniyev B.S. 2014. About type locality and finds of Darevsky's viper (Pelias darevskii (Vedmederja, Orlov et Tuniyev, 1986)), Reptilia: Viperinae) in Georgia. Russian Journal of Herpetology 4 (4): 1-10.

Tuniyev S.B., Kidov A.A., Tuniyev B.S. 2016. Additions to the description and rapid assessment of the current status of a population of the relic viper (Pelias magnifica (Tuniyev et Ostrovskikh, 2001)), (Ophidia, Viperinae) at a typical locality. Current Studies in Herpetology 16 (1/2). [In Russian]

Tuniyev S.B., Orlov N.L., Tuniyev B.S., and A. A. Kidov. 2013. On the taxonomical status of steppe viper from foothills of the south macroslope of the east Caucasus. Russian Journal of Herpetology 20 (2): 129-146.

Tuniyev S.B., Tuniyev B.S., Mazanaeva L.F. 2011. Distribution and variability of Lotiev's viper Pelias lotievi (Nilson, Tuniyev, Orlov, Hoggren et Andren, 1995) (Serpentes: Viperinae). Problems of Herpetology. Saint-Petersburg. P. 250-266. [In Russian]

Vedmederja V.I., Orlov N.L., Tuniyev B.S. 1986. On vipers systematic of Vipera kaznakowi complex. Proceedings of Zoological Institute of AN SSSR 157: 55-61. [In Russian]

Zinenko O., Stümpel N., Tuniyev B.S., Bakiev A.G., Mazanaeva L.F., Kukushkin O.V., Kotenko T.I., Strugariu A., Duisibaeva T., Nilson G., Murphy R., Orlov N.L., Ananyeva N.B., Joger U. 2011. Phylogeny of small European vipers. Abstracts of European Congress of Herpetology. Luxembourg.

Zinenko O., Stümpel N., Mazanaeva L., Bakiev A., Shiryaev K., Pavlov A., Kotenko T., Kukushkin O., Chikin Yu., Duisebayeva T., Nilson G., Orlov N.L., Tuniyev S., Ananjeva N.B., Murphy R.W., Joger U. 2015. Mitochondrial phylogeny shows multiple independent ecological transitions and northern dispersion despite of Pleistocene glaciations in meadow and steppe vipers (Vipera ursinii and Vipera renardi). Molecular Phylogenetics \& Evolution 84: 85-100.

Zinenko O., Sovic M., Joger U., Gibbs H.L. 2016. Hybrid origin of European Vipers (Vipera magnifica and Vipera orlovi) from the Caucasus determined using genomic scale DNA markers. BMC Evolutionary Biology 16 (76): 1-13. 
РЕДКИЕ ВИДЫ ЩИТКОГОЛОВЫХ ГАДЮК КАВКАЗА

\author{
Б. С. Туниев \\ Сочинский национальный парк, Россия \\ e-mail: btuniyev@mail.ru
}

Приведен обзор щиткоголовых гадюк рода Pelias Merrem, 1820, обитающих на постсоветском пространстве Кавказского экорегиона. Дана оценка современного природоохранного статуса и рекомендации к их территориальной охране.

Ключевые слова: Кавказский Экорегион, щиткоголовые гадюки, современный статус и охрана. 